\title{
Determinants of Entrepreneurial Intention of Graduating Class Students of Debre Tabor University
}

\author{
Melat Hailu, Abayneh Tesfaye, Lamesgnew Mersha and Zeleke Wale \\ Department of Management, Faculty of Business and Economics, Deber Tabor University, Ethiopia
}

\begin{abstract}
The aim of this study is to determine the entrepreneur intention of the graduating class students of Debre Tabor University. The study focus on the relation between the dependents and independent variables, the dependent variable is entrepreneurial intention and the independent variable is gender factor, family background, social factor, government role and initial capital. The study area is limited to the Debre Tabor University. The data was collected from primary sources from questionnaires which is developed based on the objectives of the study. The sample size is 348 students taken from the 2668 regular graduating class students by using both stratified a simple random sampling technique. SPSS version 20 was used to analyze the collected data the data was analyzed by using descriptive, Pearson correlation coefficient and multiple liner regression. The analysis result shows that there is a positive significant relationship between the family background, initial capital and government role while there is a negative and no significant relationship between the entrepreneurial intention and gender factor and social factor. Based on the result the researcher concluded that students with the entrepreneur intention better focus on the variables with the positive and significant relationship rather than the variables with negative and insignificant. Finally the researcher recommended to the university, they better focus on how to adjust students' mindset since the result shows most students are intended to be an entrepreneur. For the loan institution to make a change on their loan policy and attract even encourage the entrepreneur. The government is advisable to be flexible and crate a favorable rules and regulations.
\end{abstract}

Keywords:Entrepreneurial, Entrepreneurial Intention and Graduating Students

DOI: $10.7176 / \mathrm{EJBM} / 13-19-04$

Publication date:October $31^{\text {st }} 2021$

\section{INTRODUCTION}

In the past few years, becoming an entrepreneur has been a trending activity which is supported by governments all over the world. There is a growing interest in undertaking and intensifying actions to promote and support the idea of entrepreneurship as an attractive alternative to wage employment among students around the globe (Hisrich, and Peters, 2002). Moreover, as it is mentioned in his book of entrepreneur, it tells us that entrepreneurship is a dynamic process of vision, change and creation that requires an application of energy and passion towards the creation and implementation of new ideas and creative solution (Veerabhadrappa, 2009). Furthermore, according to Nabi, (2009) and Guerrero (2008) entrepreneurial intention is a state of mind that people wish to create a new firm or a new value driver inside existing organization

According to McStay, (2008) entrepreneurship is one key factor for economic development. Public, private and non-governmental organizations are taking various measures to promote entrepreneurship in different countries. There are several reasons for this tendency. First, well-educated entrepreneurs are expected to create ventures that grow faster than the enterprises of their counterparts. Second, due to the restructuring processes in organizations following intensified competition on the market worldwide, previous advantages connected with wage employment in established, mostly large enterprises such as job security or reward of loyalty currently offer less appeal, thus increasing the desirability of self-employment. Finally, the unemployment among graduates in many countries has been growing during recent years.

In developing countries, the role of entrepreneurship development is more important than that in developed countries as far as the creation of self-employment opportunities and reduction of unemployment are concerned. Ethiopia is no exception in this respect (Abiyu, 2014). Large numbers of youth are unemployed in Ethiopia one major reason that they do have less entrepreneurial intention. Some of the factors associated with this entrepreneurial intention are lack of confidence in recognizing opportunities, fear of failure to use the identified opportunities and being risk adverse (Gemechis, 2007). Moreover, most Ethiopian higher institution students expect that to be employed is the only means of getting income rather than self-employment or to be an entrepreneur. This shows that entrepreneurial thinking is lacking from Ethiopian higher education students as a result the problem of graduate unemployment is increasing (Gemechis, 2007).

In parallel with developing interest in entrepreneurship throughout the world, Ethiopia has also an increasing interest in entrepreneurship fields both among its academician, and among government policy makers and business leaders. In course of time, universities and vocational training institutes in Ethiopia has incorporated Entrepreneurship and Small Business Management in to their course curriculum so as to provide necessary exposure for students to entrepreneurial activities. Nevertheless unemployment rate was still 
increasing at increasing rate hence; this research was aimed at assessing the entrepreneurial orientation level of Debre Tabor University graduating class students.

For the past few years, the issue of entrepreneurship was strongly encouraged all over the world. The stimulation was there since it was believed that entrepreneurial ventures have positive impact on economic growth and reduction of unemployment. For instance, British government -backed national entrepreneur campaign which was launched firstly in (2011) and ever since had five national tour with main goal to inspire and support local entrepreneur since entrepreneurial ventures has a positive outcome to the society (Market Inspector, 2018).

As studies show that, among South America and Caribbean, South America has the highest level of innovation intensity and Brazil is leading country in this region with high levels in both total early -stage entrepreneurial activity and entrepreneurial activity employees. While in Asia some of the most entrepreneurial countries are Thailand (12.6\%) and Lebanon (12.1\%) make it top five in the world, taking position third and fourth in the ranking respectively. The winner of the most entrepreneurial country for the year is Brazil with 14\% new business ownership rate. Among Africa countries, Burkina Faso is the world's second most entrepreneurial country (13.5\%). Within the country the high amount of established business ownership is accompanied by the high total early stage entrepreneurial activity making it the top entrepreneurial country in Africa (Market inspector, 2018).

Though countries are trying to increase entrepreneurial activities as it mentioned above the industrial and business sectors of most developing countries are unable to absorb the large numbers of school labors seeking employment according to Bishop cited in the work of Abiyu (2014). The same is true in Ethiopia situations because as stated in the work of Gemechis, (2007) most Ethiopian higher institution students want to be employed by government or private organization. This implies that entrepreneurial intention or the intention of self-employment (being an entrepreneur) is lacking from Ethiopian higher education institution students.

This gap was there even higher education institutions in Ethiopia are offering entrepreneurship courses to the students with the aim that entrepreneurship education or courses can help students to achieve their objectives like improving entrepreneurship mindsets, enables them to more creative and self-confident in whatever they undertake and improve the attractiveness for employers, encourage innovative business startups, improvement of the role in the society. But the problem is that the students are not turning what they have learned on the class room into reality. This statement can be justified by the data that show the Ethiopian unemployment rate. For instance, as indicated in the report of Trading Economics (2018) that Ethiopian total unemployment rate reaches $(16.8 \%)$ for having a good carrier and earning money has been and is still steadily increasing.

Like other higher education institutions, Debre Tabor University is offering entrepreneurship courses to the students. However, most graduated students have the interest to be employed, there are a few or tiny percentage of students choosing to be self-employed immediately after graduating. As the finding of Abiyu (2014) shown that the triggering factors of less entrepreneurial intention are; self-confidence, shortage of human resource on funding for these types of education, attitude, and education system and also level of knowledge, cultural factor, political, economic, family background and gender factors that hinder or affect their choice. Therefore, the researchers are initiated to conduct this research because of the rate of unemployment is increasing with increasing rate especially in parallel to the number of graduating student. As a result, the researchers will try to examine the entrepreneurial intention of Debre Tabor graduating class students.

The general objective of the study is to determine the entrepreneurial intention of graduating class students of Debre Tabor University.

\section{LITERATURE REVIEW}

Entrepreneurship is an elusive concept. Some of them view it as risk bearing others call it innovation yet others considers it as thrill-seeking but It is a process by which individuals pursue opportunities regardless to the reason they currently control Stevenson\&Jarilo as cited in Barringer\&Ireland, (2010) Fred Wilson stated that Entrepreneurship is the art of turning ideas into a business. According to the conference held in the U.S.A it is defined as "Entrepreneurship is the attempt to create value through reorganization of business opportunities, the management of risk taking Entrepreneurship appropriate to the opportunities and through the communication and management skills to mobilize human, financial and material resources necessary to bring project fruition.(Barringer\& Ireland,2010). Intention is cognitive state immediately prior to executing behavior (Krueger, 2005). Thus an entrepreneurial intention is concerned with the inclination of a person's to start an entrepreneurial activity in the future (Davidson, 1995). It is a key determinant of the action of new venture creation moderated by exogenous variables such as family background, position in one's family, parent's occupation, education and training (Bird and Jelinek, 1988).

Family Background

A significant variable for, would be entrepreneurs is the background of the family they come from. Family background provides those would be entrepreneurs with an early social network for the potential entrepreneur to 
learn the social and cultural norms of a business (Vardhan and Biju, 2012). Family background has been found to be the most important factor that affects building of intention towards entrepreneurship. Early communication received by an individual from the family's occupational background would impact career choices by inducing individuals to choose a career in which they are viewed positively and impact the attitudes of individuals towards entrepreneurship (Getinet, 2003; Keat,2011). Attitude towards entrepreneurship of individuals coming from business making and business occupation family background were found to be more positive. It is possible that people from business occupational background have a better exposure to entrepreneurial efforts as they may be aware of the challenges of starting their own enterprise (Keats2011;Getinet, 2003). The findings of Laspita.(2006) shows that, family backgrounds have partial influence on entrepreneurial attitude that the father has significant intention towards the student's entrepreneurial intention. For individuals with prior exposure to family business, their previous experiences are filtered through the individual's perception of themselves based upon the reflected appraisal of significant others in the context of self-employment. Entrepreneurial behavior that is positively and immediately supported is an important and necessary requirement for a new Venture creation. An individual who is without experience and whose family is not supportive can become discouraged and ultimately not continue with starting a business (Keats, 2012)

$\boldsymbol{H}_{a} 1$ : There is strong relationship between the family background and the student entrepreneurial initiation. Gender factor

Gender has been employed by prior studies to predict entrepreneurial intention both as an independent direct predictors or as moderating variable and they showed different results between male and female. Do paco, Ferreria, Raposo, Rodriguez, and Denis (2015) compared both male and female student's participant in their studies. They proof that male students had a higher score than female students. Further, Wilson, kckul, \&Marlino (2007) used gender as an independent variable to measure self-efficiency and entrepreneurial intention. These scholars also hypothesized that there would be a significant impact of gender on the entrepreneurial intention. They proof also gender had an important key to affect self-efficiency and entrepreneurial intention. Further these scholars said that male students are more likely to start their business than female students.

The relation between gender and entrepreneurial intention makes for a very interesting study. Literature is replete with studies delving upon this linkage. Several studies report that men feel themselves more efficient and oriented to create a new venture than women (Sanchez, 2011). Zeffane (2013) in the study carried out in United Arab Emirates reported no statistically significant difference on the overall entrepreneurial potential between males and females. Gupta $(2008,2009)$ examined the role of socially constructed gender stereotypes and their influence on the entrepreneurial intentions of males and females. They did not find statistically significant difference in the entrepreneurial intention of males and females. There is much speculation in research about differences in entrepreneurial intentions between males and females. Several studies have found contrasting results. The study of Kickul (2010) among 5000middle and high students observed gender gaps in entrepreneurial interest. Among adolescence students. Zaidatol and Afsaneh (2009) found significant difference in the entrepreneurial intention between male and female students where the male students obtained a higher mean score. Shinnar(2012) examined how culture and gender shaped entrepreneurial perceptions thus in the process entrepreneurial intentions across three nations. The findings of the study reported significant gender differences in perception of barriers.. The study of Strobl (2012) is in agreement with the study of Shinnar 2012). It was reported that male students had more positive attitude towards entrepreneurship and stronger entrepreneurial school intentions

$\boldsymbol{H}_{a} 2:$ There is a significant and positive relation between students' gender and entrepreneurial intention Government role

The intention and market oriented behavior of an entrepreneur should also be influenced by the existing and anticipated economic and political infrastructure of the home country. Aldrich \&Wiedenmayer (1993) claims that the socio-political environment of the country can be also powerful that it may create or destroy entrepreneurship. For example, a "hostile" economic environment characterized by sever market fluctuation, high inflation and unemployment rate and economic instability may produce skepticism and discourage the potential entrepreneur from taking action. Economic instability in a country usually goes together with political instability as well. The lace of intellectual property right, bureaucratic barriers, corruption, lack of corporation law and proper tax arrangement are factor among many others that affect entrepreneurial intention. list those deterring criteria effective on the entrepreneurship performance of country's among which are" the ease of doing business in economy"," available of venture stability," availability of legislations for easily creation of firms", "availability of founds", "bureaucratic barriers' for business activity"....etc., thus in environment characterized by supportive political and business leaders, latent entrepreneurs became motivated to act.

$\boldsymbol{H}_{a} 3:$ There is a strong and positive relationship between government role and entrepreneurial intention.

Social factors

Another antecedent of intention is a social factor called social norm, which refers to "perceived social pressure to perform or not to perform the behavior" (Ajzen, 1991, pp 188). Past literature has shown controversial results on 
the relationship between social norm and entrepreneurial intention. Moriano (2011) confirm that social norm is a significant predictor of entrepreneurial intention. In addition, van Gelderen. (2008) also found that social norm was important in explaining intention towards entrepreneurship; they further discussed that student having entrepreneur family members and friends were having positive social norm with regard to entrepreneurship. Similarly, Carr and Sequeira (2007) and Kautonen. (2009) have also obtained positive relationship between social norm and entrepreneurial intention in their studies. Nonetheless, on the contrary, do Pa ço et al. (2011) conclude that social norm has traditionally played a weak role in predicting entrepreneurial intention and hence it is insignificant in influencing entrepreneurial intention Similarly, Shook and Bratianu (2010) also assert that social norm is not positively related to entrepreneurial intention. Other studies which support that social norm is insignificant in predicting entrepreneurial intention are such as Fini. (2009) and Sommer and Haug (2011). The contradicting results of the predictability of social norm on entrepreneurial intention have made this variable requires further investigation.

$\boldsymbol{H}_{\boldsymbol{a}} 4$ : There is a strong relationship between social factor and entrepreneurial intention

Initial capital

The results of the research have confirmed that the main factors of entrepreneurial intention can be developed during the study process. Access to Capital is a classic obstacle to starting a new business; this is at least true in developing countries with weak support from the financial institutions (Indarti, 2004). Based on the survey done previously, one of the biggest obstacles to start and grow a new business is the effort to obtain sufficient capital. Considering the importance of entrepreneurial on economic growth, then it is not surprising that the effort to alleviate this capital for entrepreneurs problem becomes an important goal for the policymakers around the world (Kerr and Nanda, 2009)

$\boldsymbol{H}_{a} 5:$ There is a significant and positive relationship between initial capital and entrepreneurial intention Conceptual frame work

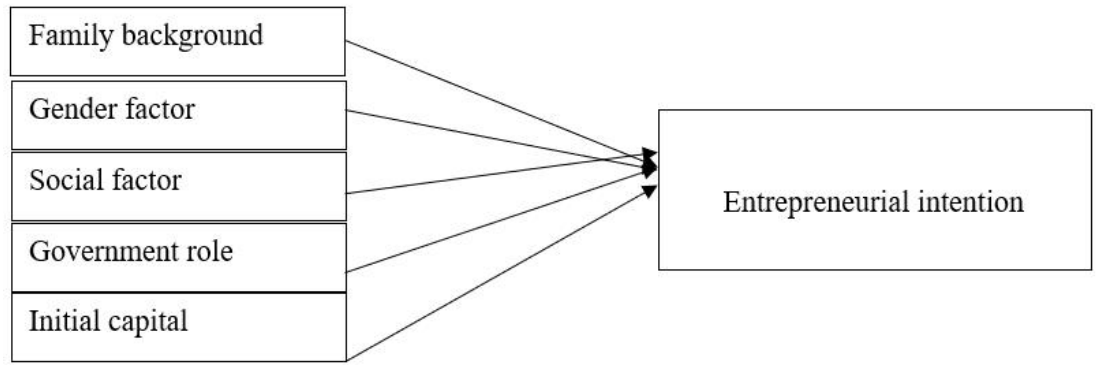

Figure 1; Conceptual framework of the study

\section{RESEARCH METHODOLOGY}

Research Design: This study employs descriptive and explanatory research design. This study used descriptive research design because it helps to ascertain and be able to describe the characteristics of variables of the researches. The study was basically an explanatory study because it shows the cause and effect relationship of dependent and independent variables.

Target Population: The target populations of this study were all regular graduating class students of Debre Tabor University. There are six faculties in the university that includes 39 departments; among them 30 departments which have regular graduating class students was considered as target populations. Therefore, 2,668 students were taken as the target populations' and 348 students were taken as sample.

Sample Size: According to Yamane (1967) sampling refers to drawing a sample or selecting a sub-set of elements from a population. Accordingly, the researchers adopted Yamane's (1967) formula to determine the sample size.

$$
\mathrm{n}=\frac{N}{1+(N)(e) 2}
$$

Where, $\quad \mathrm{N}=$ is the total population

$\mathrm{n}=$ is the sample from the population $\mathrm{e}=$ is the error term which is $5 \%$ (i.e. Confident level

\section{$\frac{2668}{1+(2668)(0.05) 2}=347.848 \approx 348$}

Sampling Techniques: Target population was huge there are 28 departments categorized under 6 faculty of the university therefore taking sample was important from time and finance perspective. Since target populations under the study were heterogeneous stratified random sampling technique was used to get representative sample form strata. Therefore, Proportional sample size from each stratum was calculated by the following formula: 


\section{sample size to be taken from the given department

$=\frac{\text { the total no of the studnts in given department }}{\text { total target population }}$

Data type and source: The study used both primary and secondary data. Primary data had been obtained from the targeted students and secondary data had been obtained from different articles, books, published and unpublished documents.

Data Collection Method: The researchers used five point Likert scale questionnaire in order to make questions interesting to respondents and thereby enhance their cooperation, ultimately to ensure maximum response rate. The questionnaire statements were evaluated on a 1-5 Likert scale on a continuous interval where ' 1 ' indicates strongly disagree with the statement, '2' disagree, '3' neutral, '4' agree and' 5 ' refers to strongly agree with the statement.

Pilot test: A pilot test was conducted on 25 samples to refine reliability and validity of the questions and identifies deficiencies in the design of questions prior actual survey. SPSS version 20.0 was used to conduct reliability test. Reliability test is determined through the interpretation of Cronbach's alpha. A reliability coefficient that indicates how way the items in a set are positively correlated to each other. (Sekaran \& Bougie, 2010)

Table 3.2 pilot test

\begin{tabular}{|l|l|l|l|l|}
\hline Variables & Construct & Cronbach's alpha & $\mathrm{N}^{0}$ of items & $\mathrm{N}^{\circ}$ of respondent \\
\hline Dependent & Entrepreneurial Intention (EI) & 0.900 & 3 & 25 \\
\hline Independent & Gender Factors (GF) & 0.842 & 4 & 25 \\
\hline Independent & Family Background(FB) & 0.912 & 4 & 25 \\
\hline Independent & Initial Capital (IC) & 0.88 & 4 & 25 \\
\hline Independent & Government Role(GR) & 0.885 & 4 & 25 \\
\hline Independent & Social Factors(SF) & 0.893 & 4 & 25 \\
\hline Over all & EI,GF,FB,IC,GR and SF & 0.779 & 23 & 25 \\
\hline
\end{tabular}

Source: own survey (2019)

All independent variables are in good reliability since Cronbach's Alpha exceeds 0.80 . The dependent variable, entrepreneurial intention is yielding excellent reliability result with Cronbach's Alpha of 0.779 . In conclusion, all variables fall under good reliability score ranges. According to Sekaran \& Bougie (2010) Cronbach's Alpha of coefficient lies from 0.7 to $<0.8$ is good and 0.8 to $<0.9$ are very good therefore after obtaining 0.779 result of reliability test, researchers distributed 348 sets of questionnaires.

Data processing: Data checking is carried out to look for any omission, error or missing data to ensure all questionnaires are fully completed (Sekaran \& Bougie, 2010). According to Sekaran and Bougie (2010), data editing is by reviewing the questionnaire to identify incomplete, inconsistent or illogical response of the answers to reinforce the accuracy and precision of the data. Data coding are numbers assigned for representing specific responses with specific questions to facilitate the data entering process and proceed further with the results (Sekaran \& Bougie, 2010). For example, by referring to first question, "Male" is coded as 1 and "Female" is coded as 2. Codes data is transcribed into SPSS version 20 for data analysis.

Methods of Data Analysis and Interpretation: The collected data was analyzed with the help of statistical program for social science (SPSS) version 20. Descriptive analysis tool such as percentage, table, and also Pearson correlation used to analyze the correlation exist among variable. Moreover in order to examine the statistical relationship between dependent and independent variables that is depicted in chapter two in the conceptual framework multiple regressions were used. Mathematical framework of the regression model is expressed as follows:

$\mathrm{EI}=\mathrm{B} 0+\beta_{1} \mathrm{FB}+\beta_{2} \mathrm{GF}+\beta_{3} \mathrm{GR}+\beta_{4} \mathrm{SF}+\beta 5 \mathrm{IC}$

Where, $\mathrm{EI}$ is dependent variable; $\mathrm{EI}=$ Entrepreneurial Intention; $\mathrm{B} 0=$ Constant Term; $\mathrm{FB}=$ family background; $\mathrm{GR}=$ government role; $\mathrm{SF}=$ social factor; $\mathrm{GF}=$ gender factor; $\mathrm{IC}=$ initial capital

\section{Result and discussion}

\section{Descriptive Analysis}

In order to analyze the demographic information such as gender, age, year of studying, and level of parent education and present family occupation the researchers' utilized descriptive statistics such as percentage and frequency and they were presented through tables. 
Table 1 Gender of the respondents

\begin{tabular}{|l|l|l|l|l|}
\hline & Frequency & Percent \% & Valid Percent & Cumulative Percent \\
\hline Male & 202 & 58.0 & 58.0 & 58.0 \\
\hline Female & 146 & 42.0 & 42.0 & 100.0 \\
\hline Total & 348 & 100.0 & 100.0 & \\
\hline
\end{tabular}

Table 1 shows the gender of respondents in percentage. Out of the total respondents $(\mathrm{N}=348), 202$ respondents $(42 \%)$ are female and 146 respondents $(58 \%)$ are male. This implies that most of the respondents are male.

Table.2 Age of the respondents

\begin{tabular}{|l|l|l|l|l|l|}
\hline & Range & Frequency & Percent & Valid Percent & Cumulative Percent \\
\hline \multirow{5}{*}{ Valid } & $19-25$ & 304 & 87.4 & 87.6 & 87.6 \\
\cline { 2 - 6 } & $26-30$ & 43 & 12.4 & 12.4 & 100.0 \\
\cline { 2 - 6 } & Total & 347 & 99.7 & 100.0 & \\
\hline Missing & System & 1 & .3 & & \\
\hline Total & 348 & 100.0 & & \\
\hline
\end{tabular}

The above table 2 show that from total respondent $304(87.4 \%)$ of them were from 19-25 years old, $43(12.4 \%)$ are $26-30 y e a r s$ old. There is $1(0.3 \%)$ missing. This implies that from the total respondent, most of the respondents are at young age.

Table 3 year of staying in the university

\begin{tabular}{|l|l|l|l|l|}
\hline Years & Frequency & Percent & Valid Percent & Cumulative Percent \\
\hline 3 & 173 & 49.7 & 49.7 & 49.7 \\
\hline 4 & 26 & 7.47 & 7.47 & 57.17 \\
\hline 5 & 144 & 41.4 & 41.4 & 98.57 \\
\hline 7 & 5 & 1.43 & 1.43 & 100.0 \\
\hline Total & 348 & 100.0 & 100.0 & \\
\hline
\end{tabular}

Based on the above table 3 among the total respondents, 173(49.7\%) of them has been stayed for three years.26 (7.47\%) of them has been stayed for four year, 144(41.4\%) of respondent has been stayed for five years and $5(1.43 \%)$ respondent has been stayed for seven years. This implies that most of the respondents (students) are social science stream students.

Table 4 respondents Father Level of education

\begin{tabular}{|l|l|l|l|l|l|}
\hline \multicolumn{2}{|c|}{} & Frequency & Percent & Valid Percent & Cumulative Percent \\
\hline Valid & Illiterate & 92 & 26.4 & 20.7 & 20.7 \\
\cline { 2 - 6 } & Primary & 78 & 22.4 & 22.5 & 43.2 \\
\cline { 2 - 6 } & Secondary & 56 & 16.1 & 16.1 & 59.4 \\
\cline { 2 - 6 } & Vocational & 20 & 5.7 & 5.8 & 65.1 \\
\cline { 2 - 6 } & University & 72 & 20.7 & 26.5 & 91.6 \\
\cline { 2 - 6 } & Other & 29 & 8.3 & 8.4 & 100.0 \\
\cline { 2 - 6 } & Total & 347 & 99.7 & 100.0 & \\
\hline Missing & System & 1 & .3 & & \\
\hline Total & 348 & 100.0 & & \\
\hline
\end{tabular}

As the above table 4 indicates the respondents fathers level of education, among 348 respondent, 92(26.4\%) of respondent father's are illiterate. $78(22.4 \%)$ respondent fathers have been joined primary schools. $56(16.1 \%)$ of respondent fathers have been joined secondary school. The $20(5.7 \%)$ of respondent father have got vocational education. $72(20.7 \%)$ of them have been joined to the universities and the rest $29(8.3 \%)$ have got other kind of education which is not listed above. This implies that most of respondent fathers are not well educated. 
Table 5 respondent mother education level

level of education your Mother achieved

\begin{tabular}{|l|l|l|l|l|l|}
\hline \multicolumn{2}{|c|}{} & Frequency & Percent & Valid Percent & $\begin{array}{l}\text { Cumulative } \\
\text { Percent }\end{array}$ \\
\hline \multirow{3}{*}{ Valid } & Illiterate & 107 & 30.7 & 30.8 & 30.8 \\
\cline { 2 - 6 } & Primary & 87 & 25.0 & 25.1 & 55.9 \\
\cline { 2 - 6 } & Secondary & 48 & 13.8 & 13.8 & 69.7 \\
\cline { 2 - 6 } & Vocational & 32 & 9.2 & 9.2 & 79.0 \\
\cline { 2 - 6 } & University & 56 & 16.1 & 16.1 & 95.1 \\
\cline { 2 - 6 } & Other & 17 & 4.9 & 4.9 & 100.0 \\
\cline { 2 - 6 } & Total & 347 & 99.7 & 100.0 & \\
\hline Missing & System & 1 & .3 & & \\
\hline Total & 348 & 100.0 & & \\
\hline
\end{tabular}

As it is indicated above on table 5 Among 348 respondents $107(30.7 \%)$ of their mother are illiterate, $87(25.0 \%)$ of their mothers has been joined the primary schools. $48(13.8 \%)$ of respondent mothers have been joined to secondary schools. $32(9.2 \%)$ have got vocational education.56 $(16.1 \%)$ of them joined to the university and $17(4.9 \%)$ have got other kind of education which is not listed above. This implies that most mothers of respondents are not educated.

Table 6 Respondent mother's occupation

\begin{tabular}{|l|l|l|}
\hline Respondent mother's occupation & Prequencies & Percentage \% \\
\hline Occupation & 178 & 51.14 \\
\hline Farmer & 74 & 21.26 \\
\hline House wife & 18 & 5.17 \\
\hline Own business & 44 & 12.6 \\
\hline Employed & 34 & 9.77 \\
\hline Other & 348 & 100 \\
\hline Total & & \\
\hline
\end{tabular}

As the above table 6 indicates that most respondent mother occupation is farming which counts 178(51.14), the house wife mothers are 74(21.26), mothers who engaged in their own business counts 18(5.17) while employed mothers are 44(12.6). Mothers who involved in other kind of occupation are 34(9.77). this implies that most of respondent are engaged in agricultural business.

Table 7 Current father occupation

\begin{tabular}{|l|l|l|}
\hline Respondent father's occupation & Percentage \% \\
\hline Occupation & Frequencies & 39.08 \\
\hline Farmer & 136 & 12.06 \\
\hline Own business & 42 & 23.56 \\
\hline Employed & 82 & 25.28 \\
\hline Other & 88 & 100 \\
\hline Total & 348 & \\
\hline
\end{tabular}

As the above table 7 indicates the majority respondent fathers are farmer 136(39.08). Fathers who are running their own business are 42(12.06) while fathers who are employed counts 82(23.56).other respondents father are engaged in other kind of occupation which is not included here and they counts $88(25.28)$. This implies that most respondent fathers are running agricultural related business.

\section{Inferential Statistics analysis}

\section{Pearson correlation coefficient analysis}

According to Sekaran and Bougie (2010), Pearson correlation analysis indicates the strength, direction and significance of bivariate relationships among all the variables that were measured at interval or ratio level. The larger the correlation coefficient, the stronger the level of association and it can be either positive or negative depending on the direction of the relationship between variables. In this study, it is used to measure the co variation and association between entrepreneurial intention and five elements (family background, government role, socio-economic, gender factor and initial capital) on hypotheses 1, 2, 3, 4, and 5. The test will be done at $5 \%$ or $1 \%$ significance level and as lee weini (2012) sited hair.jr (2007), the effect is said to be small if it is \pm 1 , the effect is said to be medium if it is \pm 3 , and it is large \pm 5 . 
Vol.13, No.19, 2021

Table 9 Pearson correlation coefficient analysis

\begin{tabular}{|c|c|c|c|}
\hline Variables & Pearson correlation & $\begin{array}{l}\text { Entrepreneurial } \\
\text { intention }\end{array}$ & $\begin{array}{l}\text { Size of the effect }( \pm 1) \text { small effect, } \\
( \pm 3) \text { medium effect and }( \pm 5) \text { large } \\
\text { effect }\end{array}$ \\
\hline \multirow[t]{2}{*}{ Entrepreneurial intention } & Pearson correlation & 1 & \\
\hline & Sig (2 tailed) & - & \\
\hline \multirow[t]{2}{*}{ Gender factor } & Pearson correlation & .133 & \multirow{2}{*}{$\begin{array}{l}\text { The effect of gender factor is less than } \\
0.3 \text { which is small effect }\end{array}$} \\
\hline & Sig (2 tailed) & .013 & \\
\hline \multirow[t]{2}{*}{ Family background } & Pearson correlation & $.598 * *$ & \multirow{2}{*}{$\begin{array}{l}\text { The effect of family background is } \\
\text { greater than } 0.5 \text { which is large effect }\end{array}$} \\
\hline & Sig (2 tailed) & .000 & \\
\hline \multirow[t]{2}{*}{ Initial capitals } & Pearson correlation & $.428 * *$ & \multirow{2}{*}{$\begin{array}{l}\text { The effect of initial capital is greater } \\
\text { than } 0.3 \text { which is moderate effect }\end{array}$} \\
\hline & Sig (2 tailed) & .000 & \\
\hline \multirow[t]{2}{*}{ Governmental factor } & Pearson correlation & $.308 * *$ & \multirow{2}{*}{$\begin{array}{l}\text { The effect of initial capital is greater } \\
\text { than } 0.3 \text { which is moderate effect }\end{array}$} \\
\hline & Sig (2 tailed) & .000 & \\
\hline \multirow[t]{2}{*}{ Social factor } & Pearson correlation & $.085^{* *}$ & \multirow{2}{*}{$\begin{array}{l}\text { There is no relationship between social } \\
\text { factor and entrepreneurial intention } \\
\text { since Pearson correlation is less than } \\
0.1\end{array}$} \\
\hline & Sig (2 tailed) & .159 & \\
\hline
\end{tabular}

Gender factor is positively related to entrepreneurial intention with a Pearson correlation coefficient of $\mathrm{r}=0.133$ and significant level of (2tailed) is 0.13 which is $0.13>0.05$ therefore there is no significant relationship among them. Family background is positively related to entrepreneurial intention with a Pearson correlation coefficient of $\mathrm{r}=0.598$ and significant level (2tailed) is 0.000 which is $<0.05$.this implies that there is a significant relationship among the variables. Initial capital and entrepreneurial intention have a positive related with a Pearson correlation coefficient 0.428 and significant level $(2$ tailed) is 0.000 which is $<0.05$. Therefore the relation is significant. Government role and entrepreneurial intention has a positive relationship with a Pearson correlation coefficient of 0.308 and significant level (2tailed) 0.000 which is $<0.005$. Therefore the relationship is significant this implies that the relation between the two variables is significant. Social factor is positively related to entrepreneur intention with a Pearson correlation coefficient of $\mathrm{r}=0.085$ and Sig (2-tailed) is 0.159 which is $>0.05$. Therefore there is a non-significant relationship between social factor and entrepreneur intention.

\section{Multiple liner regression}

Regression analysis is a statistical procedure used for estimating the relationships between one or more predictor variables and the response variable. In order to test for the influence of each independent variable (social factor, family background, gender factors, government regulation, initial capital) on dependent variable (entrepreneurial intention) multiple linear regression analysis was performed. Normality of data was ensured as indicated in Table 4.8 by using the skewness and kurtosis level which was found under acceptable level. Moreover, by reviewing the correlation matrix the multi-co linearity among the independent variables was checked.

Table 10 Multiple Liner Regression Model Summary

\begin{tabular}{|l|l|l|r|r|}
\hline \multicolumn{5}{|c|}{ Model Summary } \\
\hline Model & R & R Square & Adjusted R Square & Std. Error of the Estimate \\
\hline 1 & $.785^{\text {a }}$ & .617 & .606 & 1.84399 \\
\hline
\end{tabular}

a. Predictors: (Constant), Social Factors, Family Background, Gender Factors, Government Factors, Initial Capital

This multiple regression mode table (table 4.10) shows (R) the correlation between dependent variable (Entrepreneurial intention) and independent variables (social factors, family background, gender factors, government roles, initial capital). The $\mathrm{R}$ square is the explained variance and it is actually the square of the multiple $\mathrm{R}(0.785)^{2}$. Therefore, it is pointed out that the $\mathrm{R}$ square is 0.617 which means that $61.7 \%$ of variation of dependent variable (entrepreneurial intention) can be explained by the five independent variables (gender factor, socio factor, family background, government regulation and initial capital). This means that $38.3 \%$ of entrepreneurial intention determinant cannot be explained by the study independent variables such as gender factor, socio factor, family background, government role and initial capital. The adjusted (R2) value indicates the loss of predictive power or shrinkage. In the Model summary table the difference for the final model is small (in fact the difference between the values is $(0.617-0.606)=.0 .011$. This shrinkage means that if the model were derived from the population rather than a sample it would account for approximately about $1.1 \%$ less variance in the outcome. 
Table 11 analysis of variance (ANOVA)

\begin{tabular}{|c|c|c|c|c|c|c|}
\hline \multicolumn{7}{|c|}{ ANOVA $^{s}$} \\
\hline \multirow{2}{*}{\multicolumn{2}{|c|}{ Model }} & Sum of Squares & $\mathrm{df}$ & Mean Square & $\mathrm{F}$ & Sig. \\
\hline & Regression & 1006.110 & 5 & 201.222 & 59.177 & $.000^{\mathrm{b}}$ \\
\hline & Residual & 625.658 & 184 & 3.400 & & \\
\hline & Total & 1631.768 & 189 & & & \\
\hline
\end{tabular}

a. Dependent Variable: Entrepreneurial Intention

b. Predictors: (Constant), Social Factors, Family Background, Gender Factors, Government role, Initial Capital

Based on Table 11 the $F$ value is 59.177 with a p-value $0.000<0.01$, significance level. Thus, the overall regression model shows that the five predictors have significantly explained the dependent variable (entrepreneurial intention).

Table 12; Summary of regression coefficient

\begin{tabular}{|c|c|c|c|c|c|c|c|c|}
\hline & & & & Coefficients $^{\mathrm{a}}$ & & & & \\
\hline & & $\begin{array}{l}\text { Unsta } \\
\text { Coeff }\end{array}$ & $\begin{array}{l}\text { Irdized } \\
\text { nts }\end{array}$ & $\begin{array}{l}\text { Standardized } \\
\text { Coefficients }\end{array}$ & $\mathrm{T}$ & Sig. & $\begin{array}{l}\text { Collinearit } \\
\text { Statistics }\end{array}$ & \\
\hline & & B & Std. Error & Beta & & & Tolerance & VIF \\
\hline 1 & (Constant) & .923 & 1.072 & & .861 & .390 & & \\
\hline & Gender Factors & -.097 & .051 & -.094 & -1.918 & .057 & .877 & 1.140 \\
\hline & $\begin{array}{l}\text { Family } \\
\text { Background }\end{array}$ & .511 & .044 & .604 & 11.531 & .000 & .761 & 1.315 \\
\hline & Initial Capital & .214 & .055 & .216 & 3.861 & .000 & .664 & 1.505 \\
\hline & $\begin{array}{l}\text { Government } \\
\text { role }\end{array}$ & .233 & .054 & .214 & 4.281 & .000 & .832 & 1.203 \\
\hline & Social Factors & -.141 & .058 & -.119 & -2.416 & .017 & .862 & 1.160 \\
\hline
\end{tabular}

a. Dependent Variable: Entrepreneurial Intention

The regression coefficient $\beta$ represents the change in the outcome resulting from a unit change in the predictor and that if a predictor is having a significant impact to predict the outcome then this $\beta$ should be different from 0 (and big relative to its standard error). As indicated in the above Table 12 t-statistics can be derived that test whether a $\beta$-value is significantly different from 0 . The t-tests measures whether the predictor is making a significant contribution to the model or not. Therefore, if the t-test associated with a $\beta$-value is significant (if the value in the column labeled Sig. is less than .05) then the predictor is making a significant contribution to the model. The p-value is less than 0.05 for the three variables except gender factors and social factors.

Furthermore, Table 12 shown that the value of tolerance of each independent variable ranges from 0.664 to 0.877 and the value of variance inflation factor ranges from 1.203 to 1.505 . According to O'brien (2007), the tolerance value for all independent variables which were less than 1 and variance inflation factor which were less than 10 were considered acceptable. Hence, the results indicate no multi co linearity problem among the explanatory variables. To know the impact and relationship of independent variables on the dependent variable the regression function is in the form of

$\mathrm{EI}=\mathrm{B} 0+\beta_{1} \mathrm{GF}+\beta_{2} \mathrm{FB}+\beta_{3} \mathrm{IC}+\beta_{4} \mathrm{GR}+\beta_{5} \mathrm{SE}$

$\mathrm{EI}=0.923 \mathrm{~B} 0+(-0.097) \mathrm{GF}+0.511 \mathrm{FB}+0.214 \mathrm{IC}+0.233 \mathrm{GR}+(-1.41) \mathrm{SE}$

Based on the above regression equation family background, initial capital and government role have a positive relationship with entrepreneurial intention. Gender factor and Socio factor has a negative relationship with entrepreneurial intention. Family background is the predictor variable that contributes the highest to the variation of entrepreneurial intention, every unit increases in family background; it will increase 0.511 units in entrepreneurial intention. Other variables remain constant. The second highest predictor variable is government regulation $(\mathrm{GR}),(\mathrm{B}=0233)$ followed by initial capital .Social factor has a negative relationship with entrepreneurial intention: every one unit increases in socio- economic factor; entrepreneurial intention will decrease in 1.4 while other remains constant. Gender factor also have negative relationship with entrepreneurial intention: every one unit in gender factor increases entrepreneurial intention will decreases by 0.097 , while other remains constant.

\section{Test of hypothesis}

There are various types of methods to test the null or alternative hypothesis either rejected or accepted. The researcher had utilized the most common methods of $p$ - value test. The guideline stated that, if the value of $p$ is greater than $5 \%$ in $95 \%$ confidence interval level, we accept the Null Hypothesis and reject the alternative hypothesis or if the $\mathrm{p}$ value is less than $5 \%$, we reject the null hypothesis and accept the alternative hypothesis. 
Accordingly, based on the summary of regression coefficient of the study the hypothesis were tested as follows Table 13 Test of Hypothesis

\begin{tabular}{|c|c|c|c|c|}
\hline Hypothesis & $\begin{array}{l}\text { Test independent variable with } \\
\text { dependent variable }\end{array}$ & p-value & $\begin{array}{l}\text { Significance/beta } \\
\text { value }\end{array}$ & Result \\
\hline \multirow[t]{2}{*}{ H1 } & \multirow{2}{*}{$\begin{array}{l}\text { There is a significant and positive } \\
\text { relation between students' gender } \\
\text { and entrepreneurial intention }\end{array}$} & \multirow[t]{2}{*}{$.057>.005$} & Not significant & \multirow[t]{2}{*}{$\mathrm{H} 1$; is Rejected } \\
\hline & & & Negative & \\
\hline \multirow[t]{2}{*}{$\mathrm{H} 2$} & \multirow{2}{*}{$\begin{array}{l}\text { There is strong relationship between } \\
\text { the family background and the } \\
\text { student entrepreneurial initiation }\end{array}$} & \multirow[t]{2}{*}{$.000<.005$} & Significant & \multirow[b]{2}{*}{$\mathrm{H} 2$; is Accepted } \\
\hline & & & Positive & \\
\hline \multirow[t]{2}{*}{ H3 } & \multirow{2}{*}{$\begin{array}{l}\text { There is a significant and positive } \\
\text { relationship between initial capital } \\
\text { and entrepreneurial intention }\end{array}$} & \multirow[t]{2}{*}{$.000<.005$} & Significant & \multirow[t]{2}{*}{ H3; is Accepted } \\
\hline & & & Positive & \\
\hline \multirow[t]{2}{*}{$\mathrm{H} 4$} & \multirow{2}{*}{$\begin{array}{l}\text { There is a strong and positive } \\
\text { relationship between government } \\
\text { role and entrepreneurial intention. }\end{array}$} & \multirow[t]{2}{*}{$.000<.005$} & Significant & \multirow[b]{2}{*}{$\mathrm{H} 4$; is accepted } \\
\hline & & & Positive & \\
\hline \multirow[t]{2}{*}{ H5 } & \multirow{2}{*}{$\begin{array}{l}\text { There is a strong relationship } \\
\text { between social factor and } \\
\text { entrepreneurial intention }\end{array}$} & \multirow[t]{2}{*}{$.017>.005$} & Significant & \multirow[t]{2}{*}{$\mathrm{H} 5$; is Rejected } \\
\hline & & & Negative & \\
\hline
\end{tabular}

\section{Discusion on Major Findings}

By computing the skewness, kurtosis and multi co linerity the normal distribution were chaecked. According to , westfall (2011) histogram gives us the general idea of the shape . the skewness tells the amount and direction of the skew ( departure from the horizontal symettry) and kurtosis tells how tall and sharp the central peak is, relative to the standard bell curve.a normal distrubution has a skewness and excess kurtosis of 0 , so if the distrubiution is close to those value then itss probably close to normal distrubution.if the bulk of the data is at the left and the right tail is longer,then the ditrubution is sewed to the right or postively skewwed. If the peak is toward the right and the left tail is longer it is negatively skewwed or skewd to the left.

And for the kurtosis the higher kurtosis means the more of the variance is the rest of infrequent extreame deviation as oppose to frequent modestly skewed sized deviations. The refercene standard is a normal distrubition which has a kurtosis of 3 . Anormal distrubition has a kurtosis exaclty 3 is called meso kurtic, with $<3$ ( excess kurtosis $<0$ ) is called platykurtic compared to a normal distrubution its tail re shorter and thinner and often its central peak is lower and broader. A distrubution with kurtosis $>3$ ( excess kurtosis $>0$ ) is called lepto kurtic compared to the normal distrubition, longer and flatten and often its central peak is higher and sharper. Therefore, as it is indicated on table 4.8 and the histogram figure on 4.1 the enterprunier intention has -0.146 skewness result and -0.508 ,gender factor 0.001 skewness and -0.299 , family background result -0.252 skewness and -0.278 , initial capital -0.201 skewness and -0.150 , gender factor -0.178 skewness and 0.007 . finally the social factor has -0.102 and -0.125 skewness and kurtosis value relatively. All those varables skewness values are near to zero which is normally distributed. And since all the standard deviation(error) of skewness for all variables should be the same, then the standard deviation (error) of all varaibles fort he skewness is 0.131 while the standard for the kurtosis is 0.261 for both the dependetn and independetn varaibales.

In terms of the stated research hypotheses, the following specific observed findings emerged from the investigation: The four indpendent variables such as social factors, family background, government role, and initial capital have a positive and significant relationship with enterprinural intention.In this study gender factors, has no significant impact on enterprinural intention because the result shows 0.057 level of sig as shown in hypothesis testing table. The finding of this study indicates that the gender factor has a negative relation with no impacts towards the enterprunireal intention of the students. This finding is supported by the work of Gird and Bagraim, 2008; Engle, Dimitriadi, Gavidia, Schlaegel, Delanoe, Alvarado, He, Baume, and Wolff, 2010; Sahinidis, Giovanis and Sdrolias, 2012) that have found no statistically significant relationships between gender and EI. While there is a contrary by Czuchry and Yasin (2008) they found that the entrepreneurial intention and gender were found to be positively influential factor among Welsh students. Also the work of Abraham Abebe (2015) shows that the gender factor is the most significant variable towards the entrepreneurial intention.

And for the other variable which is family background,the finding revels that the family background has a significant impact and postive relation with students enterpruniral intention. Which is supported by Getinet's (2003)finding: Attitude towards entrepreneurship of individuals coming from business making and business occupation family background were found to be more positive. Furthermore, Devonish (2010) mention that entrepreneur parent can apply their knowledge to influence their own children to carry on their family businesses or to develop new businesses It is possible that people from business occupational background have a better 
exposure to entrepreneurial efforts as they may be aware of the challenges of starting their own enterprise Also the finding of Westhead (2003) found that being raised in a family that is entrepreneurial has a significantly impact on an individuals' intentions to start their own businesses as there is a transfer of entrepreneurial skills from parents who expect their children to eventually take over the business. But this finding is a contrary with the work of Ethiopian researchers silishei Leta and Waktole Dadi(2017) Family background factors have no significant impact on graduate's entrepreneurial.

Based on the finding initial capital and enterprunierial intention has postive relation and has a significant impact towards enterprunierial intention. The other variable which is government role has a postive and significant impact to the enterprinurial intention of the students. The social factor have no significant impact to enterprunierial intention and the variables have a negetive relationship.in the past literature this variable has shown controversial results on the relationship entrepreneurial intention. For instance, Moriano et al. (2011) confirm that social factor is a significant predictor of entrepreneurial intention. In addition, van Gelderen et al. (2008) also found that social factor was important in explaining intention towards entrepreneurship; they further discussed that student having entrepreneur family members and friends were having positive social factor with regard to entrepreneurship. Similarly, Carr and Sequeira (2007) and Kautonen et al. (2009) have also obtained positive relationship between social factor and entrepreneurial intention in their studies. Nonetheless, on the contrary, do $\mathrm{Pa}$ o et al. (2011) conclude that social factor has traditionally played a weak role in predicting entrepreneurial intention and hence it is insignificant in influencing entrepreneurial intention. Similarly, Shook and Bratianu (2010) also assert that social factor is not positively related to entrepreneurial intention. Other studies which support that social factors are insignificant in predicting entrepreneurial intention are such as Krueger et al (2000), Fini et al. (2009) and Sommer and Haug (2011).

\section{Conclusion and Recommendations}

This resarch was carried out in debre tabor university with the aim of assesing the enterprnirial intention of graduating calss students. Predictors of enterprinerual intention in Debre Tabor uniersity are gender factor,family background,social factor, Government role and initalcapital. General characterstics of respondent exept year of staying all have no impact towards the students enterprinurial intention. Students year of staying has a slight impact of enterpruniral intention of graduating class students. Students whose year of staying is $3 y$ ears are more intende to be an enterprenur. family background has the highest impact towards the enterprinur intation (EI). Gender factor has a negative relation and have a negative impact towards the enterprunireal intention of the students. The family background has a significant impact with the postive relationship with the enterprunierail intenion.therfoere a students whose family is supportive can become encouraged and ulitmately intended for being an enterprunire. Initial capital has a signifiant impact with a postiverelation with the graduating class syudentes enterpruierial intention since once the students are comitted to the idea of being an enturprunier the initalcapital is an important thng to cover the neccesary expense requiredfor new business startups. Social factor have no significant impacts towards the students entrprunier intention. Also it have a nnegative relationship, since the studenta are at the young age they prefer the dynamic changing world rather than letting the traditione and norm of the society be an obstacle for the enterprenur path. Government role variables also have a significant impact and postive relationship with the enterprenure intentionof the students. The poicy ,procedures,rule,regulation, the peace and stablity,the poltical and economics system of the country and othe government related isuues determine the students intention whether for being either enterprunur or not. The overall enterprinurial intention of the graduating class students is moderate. Socio-economi and gender factor has negative relalationship with the enterprinurial intention of ther respondetns

Since our university mission is to generate a new, highly skilled and innovative man power, then it is better to apply their effort more on influencing its students on becoming an entrepreneur through providing different training by inviting different guests and make them share the rather than being employed. It is better to adjust student mindset with the flexible government policy rule and regulations on the entrepreneurial activity as well as the whole economic system. Also the university should have a contact with the credit association and institution in order to make available funds and credits to the graduating class students after the graduation.

The loan institution is an ingredient for the availability of the fund and loan in the economy. The higher availability of initial capital for the innovators the higher they motivate to create a new venture since there is no obstacles related to the initial capital. As our finding shows the initial capital have significant impacts. Therefore the loan, credit and other finical institution should: Their interest rate to the new venture business. Make changes on the policy and procedures of their loan system. Should adjust their loan availability for the entrepreneurs equally.

It is obviously, that government and other policy makers have play a crucial role on the entrepreneurial activities that means on the creativities and innovativeness of the society .there for as a researcher finding the role of government have significant impact on entrepreneurial intention of the graduation students .so the researcher recommended that the government have to: Arrange and design a positive and smooth policy on the 
economy; that appreciate and make improvement on the innovation and creations of new venture. Make facility availability of entrepreneurial activities like that subsidy, stable economic system stable political system etc. Appreciate the infant industry and make improvement on their linkage the international market. Because this increase the creativeness and innovativeness of society.

\section{References}

Abiyu, y. (2014): Attitude orientation of students towards entrepreneurship; University of Gonder

Bishop, (1985). Curriculum Development: A textbook for students. London. MacMillan Publishers

Boulton, C. and Turner, P. (2005), Mastering Business in Asia: Entrepreneurship, Singapore: John Wiley and Sons

Do Pa ç, A.M.F., Ferreira, J.M., Raposo, M., Rodrigues, R.G. and Dinis, A. (2011), Behaviors and Entrepreneurial

Erich J. Schwarz, Malgorzata A. Wdowiak, Daniela A. Almer-Jarz and Robert J. Breitenecker, (2009). 'The effects of attitude and perceived environment condition on students' enterpreneuralintent' , Education +Training,vol. 51 No. 4, pp.272-291

FaitiraManuere, KizitoDanha,TasaraMajoni, (2013). 'Entrepreneurship attitudes and knowledge: a survey of fourth year university students 'vol 4, NO 9, pp.511-515

Famous P and Chinonye O. 92010).Global Journal of Management and Business Research Vol 10 Issue 6 (Ver 1.0), August 2010

Gemechis T. (2007). 'Attitude of college students towards entrepreneurship'

Getinet, A.(2003).Determinants of self-employment in urban Ethiopia: A panel data base evidence.

Hisrich, R. D., and Peters, M.P. (2002). Entrepreneurship (5th Ed.). New York: McGraw-Hill

Keat, Y., C. Selvarajah \& D. Meyer. 2011. Inclination towards entrepreneurship among university students: An empirical study of Malaysian university students. International Journal of Business and Social Science Vol. 2 No. 4.

Kobia, M. and Sikalieh, D. (2010), Towards a Search for the Meaning of Entrepreneurship, Journal of European Industrial Training, 34(2): 110-127.

C. R. Kothari. (2004). research methodology-methods and techniques, second revised edition

Krueger, N. (1993). The impact of prior entrepreneurial exposure on perceptions of new venture feasibility and desirability. Entrepreneurship Theory \& Practice, 18 (1), 5-21.

Krueger, N.F. Jr. and Carsrud, A.L. (1993), Entrepreneurial Intentions: Applying the Theory of Planned Behavior, Entrepreneurship and Regional Development, 5: 315-330.

Krueger, N.F. Jr., Reilly, M.D. and Carsrud, A.L. (2000), Competing Models of Entrepreneurial Intentions, Journal of Business Venturing, 15: 411-432.

Laspita, S., S. Chilosta, C. Scheren, A. Berem, K. Voigit. (2007). Students' Attitude towards Entrepreneurship: Does Gender Matter? Review of International Comparative Management Volume 8, Number 4, Pages $92 \quad 118$

Lee, L., Wong, P. K., Foo, M.D., \& Leung, A. (2011). Entrepreneurial Intentions: the Influence of Organizational and Individual Factors. Journal of Business Venturing, 26(1), 124-136

LinkedIn Company. (2002, September 6). Retrieved 11 21, 2018, from market inspector: http://www.market inspector.com.uk

Manuere, F., K. Danha and T. Majoni. 2013. Entrepreneurship Attitudes and Knowledge:

McClelland, D. (1961). The achieving society, New York: Van Nostrand.

McStay, D. (2008). An investigation of undergraduate student self-employment intention and the impact of entrepreneurship education and Enterprises previous entrepreneurial experience.

Nabi, G. and Holden, R. (2008), Graduate Entrepreneurship: Intentions, Education and Training. Education +Training, 50(7): 545-551.

Nabi, G., Holden, R. and Walmsley, A. (2010), Entrepreneurial Intentions among Students: Towards a refocused Research Agenda, Journal of Small Business and Enterprise Development, 17(4): 537-551.

Nabi, G., Holden, R. and Walmsley, A. (2010), Entrepreneurial Intentions among Students: Towards a refocused Research Agenda, Journal of Small Business and Enterprise Development, 17(4): 537-551.

Pruett, M. (2012), Entrepreneurship education: Workshops and entrepreneurial intentions, Journal of Education for Business, Vol. 87, pp.94-101. DOI: 10.1080/08832323.2011.573594

Research in Business. Institute of Interdisciplinary Business, Research VOL 4, NO 9, 511-521 Row.

S ánchez, J.C. (2013). The impact of an entrepreneurship education program on entrepreneurial

Schwarz, E.J., Wdowiak, M.A., Almer-Jarz, D.A. and Breitenecker, R.J. (2009), Sekaran, U., \& Bougie, R. (2010). Research methods for business: A skill building approach (5th ed.). Chichester, West Sussex: John Wiley \& Sons, Inc.

Survey of Fourth year University Students: Interdisciplinary Journal of Contemporary 
Temsgen,T.(2018), The Effect of Entrepreneurship education towards intention of students on Towards a refocused Research Agenda, Journal of Small Business and Enterprise

Ullah,H. et al (2012). A Study of Psychological and Non Psychological Factors of Owner university students: An empirical study of Malaysian university students. International

Vardhan, J. and S. Biju. 2012. A Binary Logistic Regression Model for Entrepreneurial venture creation,

Yamane, Taro. 1967. Statistics: An Introductory Analysis, 2nd Ed., New York: Harper and

Zikmund, W. G., Babin, B. J., Carr, J. C., \& Griffin, M. (2010). Business research methods (8th ed.). New York: South-Western/Cengage Learning.

O'brien,R.M.(2007). A caution Regarding Rules of Thumb for Variance Inflation Factors, Quality and Quantity, 41(5),673-69 